\title{
CORRELATION BETWEEN SERUM TRANSFERRIN RECEPTOR AND PERCENTAGE OF PARASITEMIA IN MALARIA. A PRELIMINARY REPORT
}

\author{
WIWANITKIT V.*, PARITPOKEE N.*, NITHIUTHAI S.**, BOONCHALERMVICHIAN C.* \& BHOKAISAWAN N.*
}

\section{Summary:}

The serum transferrin receptor (sTfR) concentration is an individual reflects of the extent of erythropoietic activity, and is a useful marker for monitoring erythropoiesis. Malaria is an important tropical disease with evidence of ineffective erythropoiesis. Although there have been previous reports concerning sTfR changes in malaria, these were descriptive studies of infected and non-infected case and there are no previous reports of correlation between sTfR levels and parasitemia in malaria. We performed an animal experiment to study the chronological changes in the level of serum transferrin receptor during infection with Plasmodium gallinaceum. The average level of sTfR in experimental chickens was $6.59 \pm 11.29 \mathrm{mg} / \mathrm{L}$. The average percentage of parasitemia was $3.4 \pm 3.5 \%$ (range 2 to $13 \%$ ). According to this study, there is significant correlation between both parameters $(r=0.921$; $p<0.05)$

KEY WORDS : malaria, transferrin receptor, parasitemia

1 $\checkmark$ ransferrin receptor (TfR) is a glycoprotein found in animals that mediates the entry of ferric transferrin from the extracellular compartment into cells (Cook et al., 1993). Up-regulation of the expression of cellular TfR occurs as a result of an inadequate tissue supply of iron, or an increased cellular demand for iron. An elevation in the soluble form of TfR (sTfR) can be detected in any disease causing alteration of iron metabolism such as anemia or hemolysis.

sTfR measurements have been widely used as an indice of iron status. The sTfR concentration has also been shown to be a more sensitive and less variable index of iron status than the more conventional serum iron, transferrin, and total iron-binding capacity (Ahluwalia et al., 1993; Cook et al., 1993). Changes in sTfR levels have studied in only a few diseases, mostly in iron deficiency anemia (Cook et al., 1993; Ferguson et al., 1992; Punnonen et al., 1997) and thalassemia (Bhokaisawan et al., 2002).

There are only limited data on the sTfR in malaria. Stoltzfus et al. (2000) found that the sTfR concentra-

\footnotetext{
* Department of Laboratory Medicine, Faculty of Medicine, Chalalongkorn University, Bangkok Thailand, 10330.

** Division of Parasitology, Department of Pathology, Faculty of Veterinarian Science, Chulalongkorn University, Bangkok, Thailand. Correspondence: Viroj Wiwanitkit. E-mail: wviroj@yahoo.com
}

Résumé : CORRÉLATION ENTRE LE TAUX DE RÉCEPTEUR SÉRIQUE DE LA TRANSFERRINE ET LA PARASTTÉmie AU COURS DU PALUdisme. ÉtUde PRÉLIMINAIRE

Le taux de récepteur sérique de la transferrine (sTRF) est corrélé à l'activité érythropoiétique, et il est à ce titre utilisé comme marqueur de l'érythropoïèse. Le paludisme est une maladie tropicale au cours de laquelle l'érythropoïèse est déffectueuse. Des études ont porté sur les modifications du sTRF au cours du paludisme, elles étaient de type descriptif, mais aucune ne s'est intéresssée à la corrélation entre les taux de sTRF et la parasitémie. Nous avons mené une étude chez l'animal afin de suivre l'évolution dans le temps des taux de sTRF lors d'une infection à Plasmodium gallinaceum. Le taux moyen de sTRF observé expérimentalement chez le poulet était de 6,59 \pm 1 1,29 mg/l, et celui de la parasitémie de 3,4 \pm 3,5\% /2 à $13 \%$. Selon cette étude préliminaire, il existe une corrélation importante entre ces deux paramètres $(r=0,921 ; p<0,05)$.

MOTS CLÉS : paludisme, transferrine, parasitémie.

tion increased in children with asymptomatic malaria with a significant correlation to the hemoglobin level. However, Huddle et al. (1999) found that malaria was not associated with sTfR concentrations that related to the hemoglobin level. These studies were descriptive describing observations in infected and non-infected cases and the conclusions were contradictory. We report here, our preliminary study of correlation between the sTfR level and percentage of parasitemia in malaria using an animal model.

\section{MATERIALS AND METHODS}

\section{ANIMAL EXPERIMENTS}

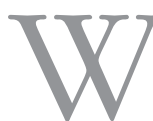
e performed animal experiments to study the chronological changes in serum transferrin receptor in chickens infected with Plasmodium gallinaceum. In our pilot study, we carried out control experimental infections of Plasmodium gallinaceum in four newborn chickens from the same batch at the Veterinarian Parasitology laboratory, Chulalongkorn University. All chickens in this study were fed with the same food and kept in the same environment. 


\section{DETERMINATION FOR STFR}

All samples were analyzed for the sTfR level using the immunoturbidimetric assay. This assay is a particle enhanced immunoturbidimetric method of soluble transferrin receptor, IDeA sTfR-IT (Orion Diagnostica; Espoo, Finland). It has been evaluated for its analytical performance in a previous study and found acceptable (Paritpokee et al., 2001). Briefly, the assay is based on the detection of an immunoreation between sTfR and sTfRspecific antibodies in liquid phase. The immunoreaction is enhanced by particles coated with sTfR-antibodies. Measurements are performed in the photometry range at 540 to 690 nanometers. The amount of immunoprecipitate is proportional to the sTfR concentration in the sample. In this study, all tests were performed using the automated clinical chemistry analyzer, Hitachi 911 (Roche-Boehringer Mannheim). All analyses were performed according to the manufacturer's instruction.

\section{CORRELATION BETWEEN THE STFR LEVEL AND PERCENTAGE OF PARASITEMIA}

16 blood samples were collected from different infected chickens. For each sample collection, $1 \mathrm{ml}$ of blood was collected from each chick. The sTfR level and percentage of parasitemia in each blood sample was evaluated. The correlation between the sTfR level and percentage of parasitemia was determined by logistic regression analysis. A statistical significant level was at $P$ value equaled to 0.05 . Statistical analyses were carried out using the SPSS 10 for Windows software (SPSS).

\section{RESULT}

\section{THE STFR LEVELS OF EXPERIMENTAL CHICKENS AND THE TREND OF CHANGE}

T The average level of sTfR in the experimental chickens was $6.59 \pm 11.29 \mathrm{mg} / \mathrm{L}$. The average percentage of parasitemia was $3.4 \pm 3.5 \%$. A significant correlation between both parameters could be detected $(r=0.921 ; p<0.05)$ (Fig. 1).

\section{DISCUSSION}

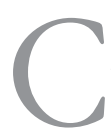
ellular iron uptake in vertebrates is mediated by transferrin receptors (TfR). A soluble form of TfR (sTfR) detected in serum is closely related to erythroid TfR turnover. Increased erythropoietic activity causes TFR synthesis to be upregulated and thereby increases the soluble transferrin receptor (sTFR) level. Determinations of sTfR concentration can reflect cellular iron demands and the erythroid proliferation rate (Huebers et al., 1990). Therefore, measurements of sTfR

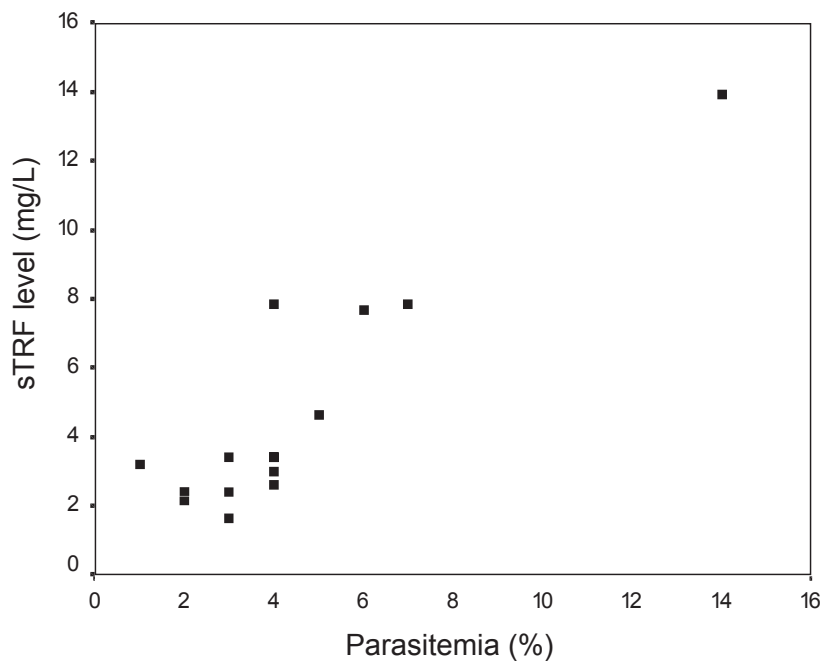

Fig. 1. - Correlation between changes in sTfR (mg/L) and the percentage of parasitemia (\%) in malarial-infected chickens.

have been introduced as a powerful tool for monitoring erythropoiesis in a variety of clinical situations (Cook et al., 1993; Ferguson et al., 1992).

Ineffective erythropoiesis has been described in studies of the bone marrow of patients with anemia and malaria (Phillips et al., 1986). Several studies found abnormalities in sTfR levels in the patients with malaria (Huddle et al., 1999; Stoltzfus et al., 2000). However, most studies were descriptive observations of infected compared to non-infected cases and as a consequence any conclusion could not be definitive. There has been no previous report on the correlation between the sTfR level and percentage of parasitemia in malaria. Here, we performed animal experiments to study the correlation between the sTfR level and percentage of parasitemia in malaria using Plasmodium gallinaceum. Consequently, interference from the nutritional status of each animal on sTfR levels could be controlled. We detected a high level of sTfR in infected chickens similar to our previous report and noted that It is approximately five times higher than in uninfected chickens (Paritpokee et al., 2002). We found a strong correlation between the sTfR level and percentage of parasitemia.

Although this is only a small pilot study, it is the first report of a correlation between sTfR levels and the percentage of parasitemia in an animal experimental model of malaria. Our results support observations on the increase of sTfR levels in malaria and the correlation between the sTfR level and percentage of parasitemia.

\section{REFERENCES}

Ahluwalia N., Lammi-Keefe C.J., Haley N.R. \& Beard J.L. Dayto-day variation in iron-status indexes in elderly women. The American Journal of Clinical Nutrition, 1993, 57, 414-419. 
Bhokaisawan N., Paritpokee N., Wiwanitkit V., BoonchalermVICHIAN C. \& NuCHPRAYOON I. Serum soluble transferrin receptor among pediatric patients with transferrin-dependant $\beta$ thalassemia/hemoglobin E. Annals of Tropical Medicine and Parasitology, 2002, 96, 427-429.

COOK J.D., SKIKNE B.S. \& BAYNES R.D. Serum transferrin receptor. Annual Revue of Medicine, 1993, 44, 63-74.

Ferguson B.J., Skikne B.S., Simpson K.M., Baynes R.D. \& CoOK J.D. Serum transferrin receptor distinguishes the anemia of chronic disease from iron deficiency anemia. The Journal of Laboratory and Clinical Medicine, 1992, 119, 385-390.

Huddle J.M., Gibson R.S. \& Cullinan T.R. The impact of malarial infection and diet on the anaemia status of rural pregnant Malawianwomen. European Journal of Clinical Nutrition, 1999, 53, 792-801.

Huebers H.A., Beguin Y., Pootrakul P., Einspahr D. \& Finch C.A. Intact transferrin receptors in human plasma and their relation to erythropoiesis. Blood, 1990, 75, 102-107.

Paritpokee N., Bhokaisawwan N., Wiwanitkit V. \& BoojchaLERMVICHian C. Methodology evaluation of a new immunoturbidimetric method for monitoring serum soluble transferrin receptor. Asian Pacific Journal of Allergy and Immunology, 2001, 19, 207-211.

Paritpokee N., Wiwanitkit V., Nithiuthai S., BoonchalermviCHIAN C. \& BHOKAISAWAN N. Change of serum transferring receptor due to malarial infection, an experiment in Plasmodium gallinaceum infected chicken model. Presented at the Joint International Meeting on Tropical Medicine 2002. Bangkok, Thailand, 2002.

Phillips R.E., Looareesuwan S., Warrell D.A., Lee S.H., KarbWang J., Warrell M.J., White N.J., Swasdichai C. \& WeaTHERALL D.J. The importance of anaemia in cerebral and uncomplicated falciparum malaria: role of complications, dyserythropoiesis and iron sequestration. The Quarterly Journal of Medicine, 1986, 58, 305-323.

Punnonen K., Irjala K. \& RajamäKi A. Serum transferrin receptor and its ratio to serum ferritin in the diagnosis of iron deficiency. Blood, 1997, 89, 1052-1057.

Stoltzfus R.J., Chwaya H.M., Montresor A., Albonico M., SAVIOLI L. \& TiELSCH J.M. Malaria, hookworms and recent fever are related to anemia and iron status indicators in 0- to 5-years old Zanzibari children and these relationships change with age. The Journal of Nutrition, 2000, 130, 1724-1733.

Reçu le 18 décembre 2006 Accepté le 18 janvier 2007 